Diabetologia (1995) 38: 255-261

\title{
Acute onset of diabetic pathological changes in transgenic mice with human aldose reductase cDNA
}

\author{
T. Yamaoka ${ }^{1}$, C. Nishimura ${ }^{2}$, K. Yamashita ${ }^{1}$, M. Itakura ${ }^{1}$, T. Yamada ${ }^{2}$, J. Fujimoto ${ }^{2}$, Y. Kokai ${ }^{2}$ \\ ${ }^{1}$ Division of Endocrinology and Metabolism, Institute of Clinical Medicine, University of Tsukuba, Tsukuba-City, Japan \\ ${ }^{2}$ Departments of Pediatric Pharmacology and Pathology, National Children's Medical Research Center, Tokyo, Japan
}

Summary To investigate the role of human aldose reductase (hAR) in the pathogenesis of diabetic complications, we generated transgenic mice carrying hAR cDNA driven by the murine MHC class I molecule promoter (hAR-Tg). Northern and Western blot analyses and immunoassay of hAR revealed that both hAR mRNA and the protein were expressed in all tissues tested. Thrombosis in renal vessels and fibrinous deposits in Bowman's capsule were observed in 6-week-old hAR-Tg mice fed a normal diet. Ingestion of a $30 \%$ glucose diet for 5 days caused sorbitol concentrations in the liver, kidney, and muscle of hAR-Tg mice to be elevated significantly. Seven-week-old hAR-Tg mice fed a $20 \%$ galactose diet for 7 days developed cataracts and occlusion of the retinochoroidal vessels, in addition to pa- thological changes in the kidney. Despite an elevated aldose reductase level in hAR-Tg mice and their intake of an aldose diet, no histopathological changes were found in other tissues, including the brain, lungs, heart, thymus, spleen, intestine, liver, muscle, spinal cord, or sciatic nerve. Results suggest that target organs of diabetic complications, such as the kidney, lens, and retina are sensitive to damage associated with a high level of AR expression, but other organs are not; the susceptibility of each organ to diabetic complications is determined by not only hAR but also other factors. [Diabetologia (1995) 38: 255-261]

Key words Transgenic mice, aldose reductase, diabetic angiopathies, diabetic retinopathy, diabetic nephropathies.
Diabetic complications develop gradually over many years via intricate mechanisms that include an acceleration of the polyol pathway [1-6], a decrease in myo-inositol [1-6], and protein glycation [6-9]. This intricacy makes it difficult to clarify the roles of these factors in the pathogenesis of diabetic complications. Acceleration of the polyol pathway in diabetes is considered to play a key role in the onset of such complications as neuropathy [2-6], retinopathy $[1,2]$, and cataract formation [2]. In fact, the distribution of al-

Received: 27 May 1994 and in revised form: 27 July 1994

Corresponding author: Dr. T. Yamaoka, Otsuka Department of Clinical and Molecular Nutrition, University of Tokushima, School of Medicine, Kuramoto-Cho, Tokushima City, 770, Japan

Abbreviations: hAR, Human aldose reductase; hAR-Tg, transgenic mice carrying hAR, cDNA; PCR, polymerase chain reaction; ARI, aldose reductase inhibitor. dose reductase (AR), which has been detected immunohistochemically in lens epithelium $[10,11]$, the pericytes of retinal capillary vessels [12], glomerular podocytes [11], and the Schwann cells of peripheral nerves [13], coincides with the localization of early diabetic complications. However, it is not clear to what extent the polyol pathway accounts for the progression of diabetic complications, whether the susceptibility of each tissue depends chiefly on the level of AR, and whether the introduction of AR cDNA to tissues resistant to diabetic conditions, e.g., the central nervous system and the liver, can convert them into target organs. To clarify these questions, we generated transgenic mice (hAR-Tg) carrying the murine $H-2 K^{d}$ (MHC class I molecule) promoter fused to human AR cDNA [14]. With this promoter, it was anticipated that hAR would be expressed in all living cells and that the effect of $\mathrm{hAR}$ on various tissues could be studied simultaneously in hAR-Tg, 


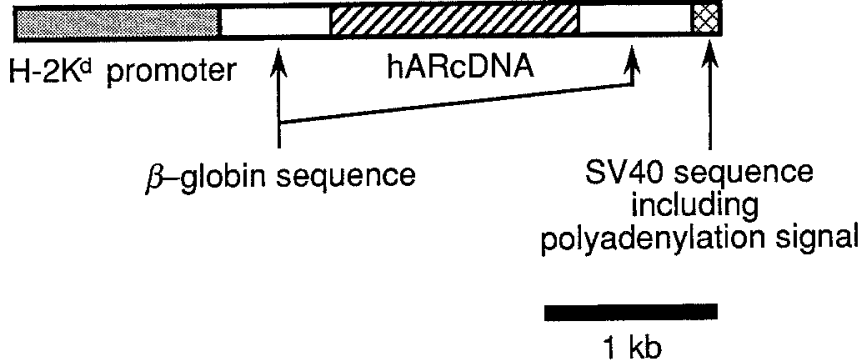

Fig. 1 The DNA construct microinjected into fertilized mouse eggs. The sequence that includes the exon-intron organization of the $\beta$-globin gene was inserted for efficient expression of the transgene [16]

although its level of expression may vary among tissues $[15,16]$.

\section{Materials and methods}

Production of $h A R-T g$. The plasmid that includes human interleukin-2 receptor cDNA with a murine $H-2 K^{d}$ promoter was a gift from Dr. T. Honjo [15]. pKCR $H-2 K^{d}$ hAR was constructed by replacing human interleukin-2 receptor $\mathrm{CDNA}$ with the full length $(1.4 \mathrm{~kb})$ of hAR cDNA [14] with EcoRI linkers on each side. The direction and sequence of the hAR cDNA insert in this plasmid were confirmed by dideoxy sequencing [17]. The $P v u I I$-Sal I restriction fragment of pKCR $H-2 K^{d}$ hAR (Fig. 1) was purified by agarose gel electrophoresis and the glass powder method, and microinjected into the male pronuclei of zygotes obtained from super-ovulated BDF1 $(\mathrm{C} 57 \mathrm{BL} / 6 \times \mathrm{DBA} / 2)$ female mice crossed with male BDF1. The zygotes were implanted in pseudopregnant female mice and allowed to develop. DNA was extracted from tail snips of live offspring by the proteinase K/SDS method [18]. The presence of the transgenes was detected by Southern blot analysis [17]. To avoid cross-hybridization to the murine AR gene, the region of hAR cDNA between the stop codon and the polyadenylation site ( $252 \mathrm{bp}$ ), which is a sequence specific to the transgene, was amplified by polymerase chain reaction (PCR) with the primers 5'TATGGCCTGTGTCACTC3' and 5'GGATTCCAGTTCCAAGC3' as the probe. Because the sizes of hAR cDNA and mouse genome are $1.4 \times 10^{3}$ and $3 \times 10^{9}$ bp respectively, and $30 \mu \mathrm{g}$ of DNA were applied on a lane, $14 \mathrm{pg}\left(30 \times 10^{-6} \times 1.4 \times 10^{3} / 3 \times 10^{9}\right)$ of hAR cDNA on one lane correspond to one copy of transgene in a mouse cell. Therefore, 14, 140, and $1400 \mathrm{pg}$ of hAR cDNA were hybridized with the probe as the indicators of 1,10 , and 100 copies of the transgene, respectively; the copy number of integrated transgenes was determined from the intensity of each radioactive band in Southern blotting. Six to eight-week-old $\mathrm{hAR}-\mathrm{Tg}$ mice and their littermates were used in the following studies.

$R N A$ analysis. Total RNA was isolated from the tissues of one male hAR-Tg mice and its littermate by the guanidinium thiocyanate/cesium chloride method and exactly $30 \mu \mathrm{g}$ of total RNA from each tissue was used for Northern blot analysis [17]. The DNA probe was prepared by the same method as that used for Southern blot analysis, except that the only strand of hAR cDNA complementary to hAR mRNA was labelled with the primer 5'GGATTCCAGTTCCAAGC3' and the Klenow fragment of DNA polymerase to achieve high specificity and sensitivity.

Western blot analysis. The homogenate of each organ from one female hAR-Tg mouse and its littermate was centrifuged at $3,000 \times g$ for $15 \mathrm{~min}$ and the supernatant was applied to Western blot analysis, according to a standard procedure [19]. Rabbit polyclonal antibody against hAR (1,000-fold dilution) was used, with donkey polyclonal antibody against rabbit IgG labelled with ${ }^{131} \mathrm{I}$ (1,000-fold dilution, $111 \mathrm{TBq} / \mathrm{mmol}$; Amersham Int., Amersham, Bucks., UK) as the second antibody. Protein concentrations were determined with a protein detection kit (Bio-Rad Labs., Richmond, Calif., USA).

Purification and assay of $A R$ activity. AR was purified from the gluteal and femoral muscles of 10 mice $(5$ males and 5 females), as described by Morjano and Flynn [20]. The purification steps consisted of homogenizing the muscles from 10 mice together in phosphate buffered saline ( $\mathrm{pH} 7.0$ ) containing $5 \mathrm{mmol} / 12$-mercaptoethanol, ammonium sulphate fractionation from 50 to $80 \%$, and chromatography on Sephadex G100, Blue-Sepharose CL-6B, and DEAE-Sephacel (Pharmacia LKB, Uppsala, Sweden). The activity of purified AR was determined spectrophotometrically by measuring the decrease in absorbance at $340 \mathrm{~nm}$ caused by the oxidation of NADPH, as previously described [21]. One unit of enzyme activity is defined as the amount of enzyme catalysing the oxidation of $1 \mu \mathrm{mol}$ of $\mathrm{NADPH} / \mathrm{min}$ under the present assay conditions.

Quantification of $h A R$ protein. hAR protein in mouse tissues was measured directly by an antibody-sandwich enzymelinked immunosorbent assay, according to a method described previously [22].

Determination of sorbitol concentration. After hAR-Tg mice and their littermates had been fed for 5 days with mouse chow containing $30 \%$ glucose (Oriental Yeast Co., Chiba, Japan), with or without an aldose reductase inhibitor (ARI), $1 \%$ epalrestat (Ono Pharmaceutical Co., Osaka, Japan), the liver, kidneys, and muscles of each mouse were excised and homogenized. The homogenate was centrifuged at $10,000 \times g$ for $20 \mathrm{~min}$ and the pellet was discarded. The protein concentration of each sample was determined and made uniform with the others by dilution. An equal volume of ice-cold $1 \mathrm{~mol} / \mathrm{l} \mathrm{per}-$ chloric acid was added to the sample for the exclusion of protein. After centrifugation, the supernatant was neutralized with $1 \mathrm{~mol} / 1 \mathrm{KOH}$ and then applied to a determination kit for sorbitol (Boehringer Mannheim Biochem., Indianapolis, Ind., USA), in which sorbitol was oxidized in the presence of sorbitol dehydrogenase and NAD, and the increase in NADH was measured spectrophotometrically.

Histopathological study. Each tissue obtained from the hAR$\mathrm{Tg}$ mice and their littermates was fixed in formalin/ phosphate buffered saline, sectioned, and stained with haematoxylin and eosin, phosphotungstic acid-haematoxylin, and periodic acidmethenamine-silver. Furthermore, hAR-Tg mice and their littermates were fed $20 \%$ galactose chow (Oriental Yeast Co.), with or without $1 \%$ epalrestat, for 1 week. Both eyes were removed and the lenses were isolated. Each lens was examined for the presence of cataract under an inverted microscope. Because the murine retina is nourished chiefly by the choroidal arteries and the separation of retina from choroid was accompanied by tissue damage, the retinochoroidal vessels were simultaneously observed under the microscope. Tissues from mice fed $20 \%$ galactose chow were also fixed, sectioned, and stained with haematoxylin and eosin. 
T. Yamaoka et al.: Transgenic mice expressing aldose reductase

\section{Statistical analysis}

Data are presented as mean $\pm \mathrm{SD}$. For comparisons of data, Student's unpaired $t$-test was used. Probability less than 0.05 was considered statistically significant.

\section{Results}

Production of $h A R-T g$. Southern blot analysis of tail DNA from 77 live-born mice revealed that 17 mice contained integrated copies of the transgene. The number of copies integrated into hAR-Tg mice ranged from about 2 to 200 (data not shown). Because a larger amount of hAR would be expressed in a founder with a higher copy number and the effect of hAR on tissue damage would be augmented by a higher expression level of hAR, four female and three male hAR-Tg mice with more than 50 copies were selected as founders. Although four female founders were mated with normal male mice, they proved to be infertile or could not maintain a pregnancy. Of the three male founders, two were infertile and only one could impregnate female mice and produce offspring that could be bred. Homozygous hAR-Tg mice could not, however, be generated, because all female hARTg were infertile. Therefore, only hemizygous hAR$\mathrm{Tg}$ mice were examined in this study.

$R N A$ analysis. In all tissues tested, hAR mRNA was clearly detected and showed an increase in size (up to approximately $1 \mathrm{~kb}$ ), as compared with that from HeLa cells (Fig.2). Although the amount of total RNA obtained from the retina from one hAR-Tg mouse was less $(5 \mu \mathrm{g})$ than that from other tissues, hAR mRNA was detected in the retina of hAR-Tg mice (data not shown). In an experiment performed simultaneously using the identical procedure, no hAR mRNA signals were observed in total RNA from the organs of the littermate (data not shown).

Western blot analysis. Radioactive bands at the position corresponding to the molecular weight of hAR were recognized in all tissues tested (Fig.3). Although the samples from a littermate were simultaneously treated by an identical procedure, hAR protein was not detected in the organs from the littermate (data not shown).

Purification and assay of $A R$. The yield of hAR purified from the muscles ( $35 \mathrm{~g})$ of hAR-Tg mice was $53.5 \mu \mathrm{g}$, including murine AR. Sodium dodecyl sulphate polyacrylamide gel electrophoresis showed double AR bands (data not shown). The amount of murine AR included in the preparation was estimated to be about $8.5 \mu \mathrm{g}$, because the same amount was purified from the muscles ( $35 \mathrm{~g}$ ) of littermates by the identical purification procedure. The total activity of purified AR from hAR-Tg mouse muscles was 0.11

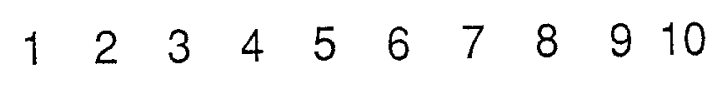

$28 S>$

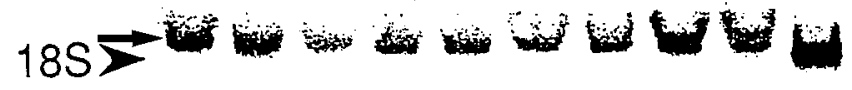

Fig. 2 Northern blot analysis for hAR mRNA. Total RNA was extracted from various organs of hAR-Tg mice by the guanidinium thiocyanate/cesium chloride method. In all organs tested, hAR mRNA (indicated by an arrow) was detected by an image analyser (BAS 2000, Fuji, Japan). The size of hAR mRNA was larger (up to approximately $1 \mathrm{~kb}$ ) than that from HeLa cells (lane 10) used as a positive control. Lane 1, 1; lane 2 , thymus; lane 3, muscle; lane 4, heart; lane 5, kidney; lane 6 , intestine; lane 7 , brain; lane 8 , lung; lane 9 , spleen

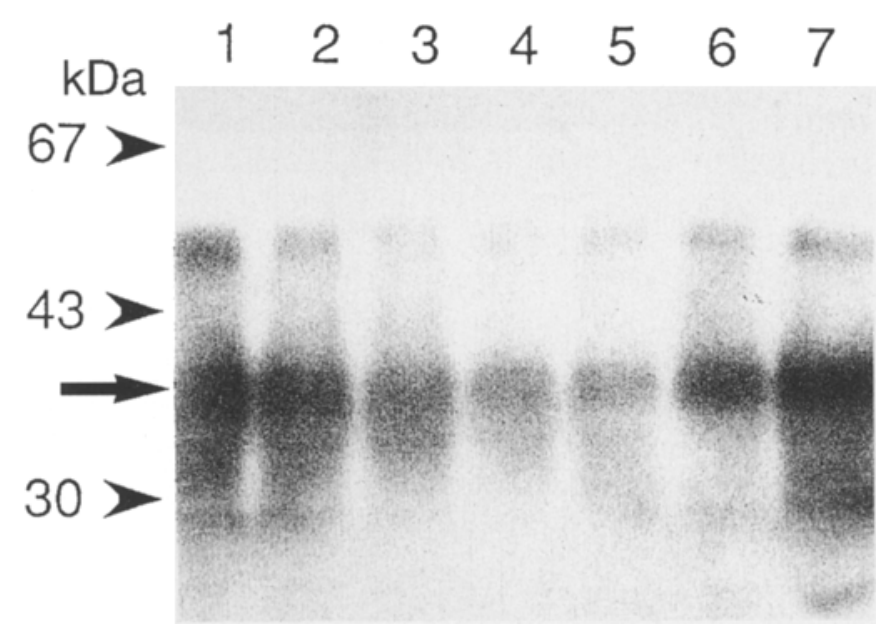

Fig.3 Western blot analysis for hAR. A sample of each organ containing $30 \mu \mathrm{g}$ of protein was applied to the corresponding lane. The arrow in the figure indicates the molecular weight of hAR. Lane 1, liver; lane 2, muscle; lane 3, heart; lane 4, kidney; lane 5, brain; lane 6, lung; lane 7, HeLa cells

$\mathrm{U}$ and that from the littermates was $0.02 \mathrm{U}$, which corresponded to the result of protein yields. Thus, AR activity in hAR-Tg mouse muscles was 5-6 times higher than that in the muscles of littermates, an increase which was due to an increased amount of AR, not activation of AR.

Quantification of hAR protein. The highest level of hAR was detected in the liver, followed by sciatic nerve and kidney of hAR-Tg mice. hAR was not detected in the tissues of littermates (Table 1).

Determination of sorbitol concentration. As shown in Table 2, sorbitol concentration in the liver, kidney, and muscle of hAR-Tg mice after the intake of $30 \%$ glucose chow for 5 days increased by factors of 1.7 , 2.1 , and 2.0, respectively, as compared with a normal diet. ARI (epalrestat) suppressed the increase in sor- 
Table 1. Determination of hAR by immunoassay

\begin{tabular}{lll}
\hline Organ & AR (ng/mg protein) & \\
\hline & hAR-Tg & Littermate \\
\hline Liver & 676.3 & ND \\
Sciatic nerve & 172.6 & ND \\
Kidney & 112.8 & ND \\
Lens & 2.4 & ND \\
\hline
\end{tabular}

ND, not detected

bitol concentration in liver, kidney, and muscle of hAR-Tg mice. However, sorbitol concentrations in the liver, kidney, and muscle of the littermates were not changed significantly by ingestion of a $30 \%$ glucose diet, with or without ARI. The sorbitol concentrations in hAR-Tg mice were significantly higher than those in littermates only when a $30 \%$ glucose diet without ARI had been fed to both groups of mice. In hAR-Tg mice fed normal chow, sorbitol concentrations in the liver, kidney, and muscle tended to be higher than those in littermates also fed normal chow.

Histopathology study. Out of five hAR-Tg mice fed a normal diet, thrombi of the renal vessels developed in three mice (Fig. 4A), and multiple fibrinous deposits the Bowman's capsule of many glomeruli were found in four mice (Fig.4B). These deposits were stained dark blue with phosphotungstic acid-haematoxylin (Fig. 4C). Light microscopy revealed no histopathological abnormality in brain, lungs, heart, thymus, spleen, intestine, liver, muscle, spinal cord, and sciatic nerve of $\mathrm{hAR}-\mathrm{Tg}$ mice.

In 15 hAR-Tg mice fed a $20 \%$ galactose diet for 7 days, cataracts and occlusion of retinochoroidal vessels developed in five mice, cataract alone developed in two and vascular occlusion only developed in two (Fig.5A). Neovascularization was not found. In 14
hAR-Tg mice fed a $20 \%$ galactose diet with $1 \%$ ARI (epalrestat), mild cataracts were observed in two and there was no evidence of vascular occlusion. Thrombi of the renal vessels and fibrinous deposits in Bowman's capsules were observed in the kidneys of hAR-Tg mice fed a $20 \%$ galactose diet. In these galactose-fed hAR-Tg mice, however, no histopathological abnormality occurred in other tissues, including brain, lungs, heart, thymus, spleen, intestine, liver, muscle, spinal cord, and sciatic nerve. In 17 age-matched littermates fed either normal chow or a $20 \%$ galactose diet, no histopathological abnormality was demonstrated.

\section{Discussion}

Production of $h A R-T g$. Although seven founders (three males and four females) with a high copy number of transgenes were generated, all the females and two of the males were infertile. The fact that some female hAR-Tg mice conceived but had their fetuses die in utero suggests that placental function may be impaired in hAR-Tg mice. Because AR exists in the placenta [23] and it is believed that AR contributes to normal placental function, an excess of AR in the placenta may exert a harmful influence on fetal growth. The infertility of two male founders may be attributable to impotence or ejaculatory dysfunction caused by an elevated level of hAR. It has been suggested that putative $A R$ is expressed abundantly in mouse vas deferens under the regulation of testosterone and plays an important role in sperm maturation and survival [24]. Furthermore, AR was immunohistochemically located in Sertoli cells which are essential to spermatogenesis [25]. Deregulated expression of $A R$ in the vas deferens or Sertoli cells might affect the fertility of male hARTg mice.

Table 2. Concentration of sorbitol after administering a diet containing $30 \%$ glucose, with or without ARI (epalrestat), for 5 days

\begin{tabular}{|c|c|c|c|c|c|c|}
\hline & \multicolumn{2}{|l|}{ Liver } & \multicolumn{2}{|l|}{ Kidney } & \multicolumn{2}{|l|}{ Muscle } \\
\hline & Littermates & hAR-Tg & Littermates & hAR-Tg & Littermates & hAR-Tg \\
\hline $\begin{array}{l}\text { Normal diet } \\
\text { without ARI }\end{array}$ & $2.39 \pm 0.35$ & $3.03 \pm 0.54$ & $1.87 \pm 0.42$ & $2.60 \pm 0.57$ & $1.01 \pm 0.27$ & $\prod_{\mathrm{a}} \quad 1.22 \pm 0.24$ \\
\hline $\begin{array}{l}\text { Normal diet } \\
\text { with } 1 \% \text { ARI }\end{array}$ & $2.31 \pm 0.44$ & $2.28 \pm 0.68$ & $1.71 \pm 0.50$ & $1.96 \pm 0.62$ & $1.20 \pm 0.21$ & $1.14 \pm 0.38$ \\
\hline $\begin{array}{l}30 \% \text { glucose diet } \\
\text { without ARI }\end{array}$ & $\begin{array}{c}2.19 \pm 0.39 \\
\mathrm{~L}_{\mathrm{a}}\end{array}$ & $5.27 \pm 0.82$ & $\begin{array}{c}2.08 \pm 0.41 \\
\operatorname{La}=\end{array}$ & $5.71 \pm 1.03$ & $\begin{array}{c}1.19 \pm 0.29 \\
\mathrm{~L} a\end{array}$ & $2.47 \pm 0.42$ \\
\hline $\begin{array}{l}30 \% \text { glucose diet } \\
\text { with } 1 \% \text { ARI }\end{array}$ & $2.51 \pm 0.59$ & $3.43 \pm 0.56$ & $2.05 \pm 0.49$ & $3.11 \pm 0.66$ & $1.11 \pm 0.19$ & $\begin{array}{l}L \quad 1.33 \pm 0.30 \\
(\mathrm{nmol} / \mathrm{mg} \text { protein) }\end{array}$ \\
\hline
\end{tabular}

Values are means \pm SD in five mice. ${ }^{a} p<0.05$. The feeding of a $1 \%$ ARI diet corresponds to the daily administration of ARI at a dose above $100 \mathrm{mg} / \mathrm{kg}$ 


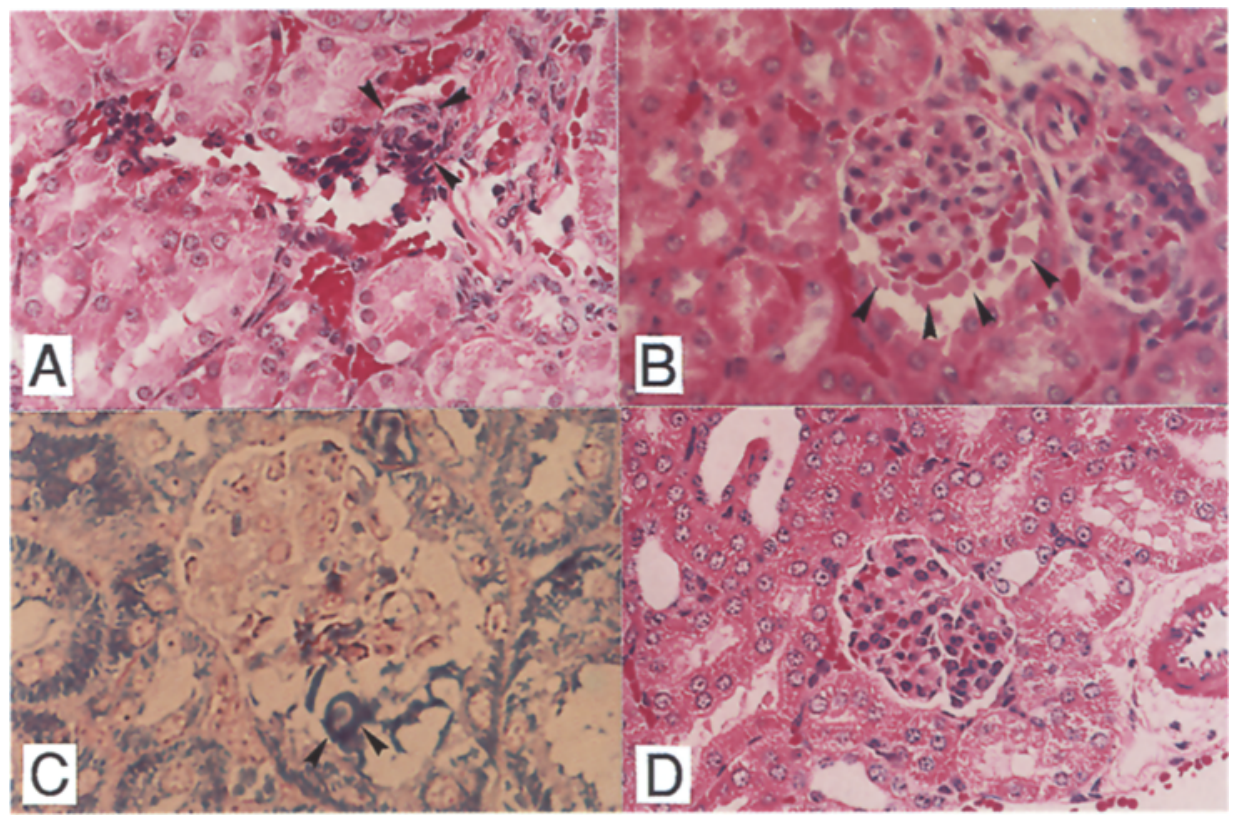

Fig.4 A-D. Histopathological changes in the kidneys of hAR-Tg mice. A Thrombotic formation (arrowheads) in a renal small artery of hAR-Tg mouse. HE stain, $\times 200$. B Fibrinous deposits (arrowheads) in the Bowman's capsule of an hAR-Tg mouse. These deposits resemble the capsular drops in a diabetic exudative lesion. HE stain, $\times 200$.

C Phosphotungstic acid-haematoxylin staining. The drops (arrowheads) were stained dark blue. $\times 400$. D A glomerulus in a littermate. $\mathrm{HE}$ stain, $\times 200$
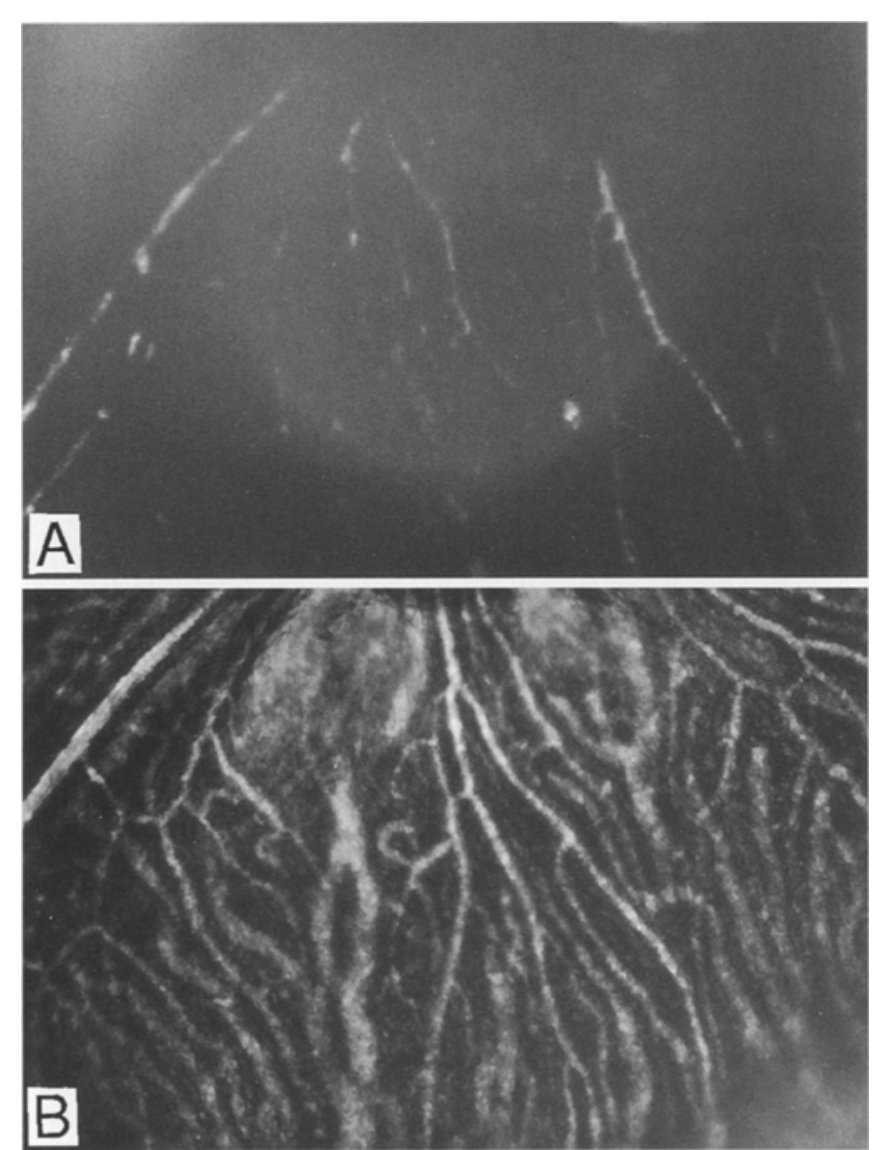

Fig.5A, B. Occlusion of the retinochoroidal vessels of an hAR-Tg mouse after ingestion of a $20 \%$ galactose diet for 7 days. A hAR-Tg. $\times 100$. B An age-matched littermate given the same diet for 7 days. $\times 100$
RNA analysis. hAR mRNA transcribed in hAR-Tg mice was larger in size (up to approximately $1 \mathrm{~kb}$ ) than that in HeLa cells. Cross-hybridization of the DNA probe in Northern blot analysis to murine AR mRNA was unlikely because the sequence used as the probe was one specific to hAR cDNA and crosshybridization of this probe to murine AR cDNA was not found in Southern blot analysis. The increase in mRNA size was probably attributable to elongation of the poly A tail or to the additional $\beta$-globin sequence (Fig. 1).

Although it has been reported that interleukin-2 mRNA driven by the $H-2 K^{d}$ promoter is expressed mainly in the thymus, spleen, bone marrow, lung, skin, muscle, and liver $[15,16], \mathrm{hAR}$ mRNA in hAR$\mathrm{Tg}$ mice was expressed to a similar extent in various tissues (Fig. 2).

Purification and assay of $A R$. The yield and activity of AR from the muscles of hAR-Tg were clearly higher than those of AR from the muscles of littermates, although accurate determination of hAR activity was difficult because of the protein loss during purification and the coexistence of murine AR.

Quantification of $h A R$. Antibody-sandwich immunosorbent assay showed high levels of hAR protein expressed in the liver, kidney, and sciatic nerve of hAR-Tg mice. In this study, the specificity of the assay method was substantiated by the failure to detect $\mathrm{hAR}$ in tissues from littermates. This result indicates that the anti-hAR antibody used in the assay system does not cross-react with murine AR. In the lens of $\mathrm{hAR}-\mathrm{Tg}$ mice, the amount of AR per mg protein was much smaller than in the liver, kidney, and nerve. This low concentration of hAR may be due to 
the large amount of crystallin and the relatively small number of living cells per total protein in the lens.

Determination of sorbitol concentration. Despite the high concentration of AR level in tissues of hAR-Tg mice, the concentration of sorbitol in the liver, kidney, and muscle of hAR-Tg mice fed a normal diet was modest, as compared with that in littermates. This result indicates that glycolysis in hAR-Tg mice was normal. The concentration of sorbitol in hAR$\mathrm{Tg}$ mouse tissues was enhanced by ingestion of a $30 \%$ glucose diet. The load imposed by a $30 \%$ glucose diet may exceed the capacity for glucose consumption through the glycolytic pathway in the liver, kidney, and muscle of hAR-Tg mice.

Histopathology study. Among tissues studied in hAR$\mathrm{Tg}$ mice, the predominant pathological changes were cataract, the occlusion of retinochoroidal and renal vessels, and deposits in the Bowman's capsule. Lens, retinochoroidal and renal vessels, and glomeruli are the structures susceptible to diabetic complications. Diabetic cataract can be induced simply by the accumulation of polyols, without other metabolic disorders [26]. Deposits in Bowman's capsule in hAR-Tg mice resembled the "capsular drop," a manifestation of the exudative lesion that is found together with "fibrin cap" in diabetic glomeruli [27]. This similarity may indicate that accumulation of polyol leads to the diabetic exudative lesion.

Because intake of a $20 \%$ galactose diet in hAR-Tg mice should lead to an elevation of plasma galactose concentration, it can be assumed that galactitol accumulated in all vascular cells and that vascular damage occurred in every organ. However, vascular damage in hAR-Tg mice after the intake of a $20 \%$ galactose diet for 7 days occurred only in retinochoroidal and renal vessels, which was suppressed by ARI. Tissues originally insensitive to diabetic complications, such as the brain and liver, did not exhibit histopathological changes, although the expression of AR was high in hAR-Tg mice. These results suggest strongly that the target organs of diabetic complications, the eye and kidney, are sensitive to an elevated AR level and tend to develop pathological changes. In contrast, organs naturally refractory to diabetic complications, such as the liver, were not affected in hAR-Tg mice; augmentation of the polyol pathway in the organs was the only abnormality in glucose metabolism. This finding suggests that the susceptibility of each organ to diabetic complications depends not only on the AR level but on other factors as well. Indeed, the organs in which glucose uptake is not insulin-dependent are freely permeable to glucose, and a rise in free intracellular glucose sufficient to saturate and exceed that required for hexokinase activity occurs under diabetic conditions so that additional glucose is available for metabolism by the polyol pathway. On the other hand, glucose uptake into insulin-dependent cells is impaired in diabetes because of decreased insulin action. Therefore, glucose concentration in insulin-dependent cells may not be elevated to the extent that hexokinase is saturated, and sorbitol accumulation may be suppressed even in the presence of excessive AR.

No proliferative changes were observed in eyes or kidneys in hAR-Tg mice. Acute vascular occlusion may completely break down the mechanisms for cell repair and proliferation. In dogs, 3 years or longer of dietary modification were needed to induce development of a diabetic-like simple retinopathy [28]. To determine whether diabetic-like proliferative retinopathy occurs, and how long the organs refractory to diabetic complications continue to function normally in hAR-Tg mice will require a long-term study with an appropriate protocol. Nevertheless, hAR-Tg mice should prove useful for studying diabetic complications and for estimating any effect of ARI, because the diabetic-like lesions develop rapidly. Moreover, because the effect of ARI on AR differs in various animal species [29], data obtained from the administration of ARI to hAR-Tg mice would be useful for the clinical application of ARI to human diabetic subjects.

\section{References}

1. Frank RN (1991) On the pathogenesis of diabetic retinopathy: a 1990 update. Ophthalmol 98: 586-593

2. Raskin P, Rosenstock $\mathbf{J}$ (1987) Aldose reductase inhibitors and diabetic complications. Am J Med 83: 298-306

3. Bays HE, Pfeifer MA (1988) Peripheral diabetic neuropathy. Med Clin North Am 72: 1439-1464

4. Harati Y (1987) Diabetic peripheral neuropathies. Ann Intern Med 107: 546-549

5. Greene DA, Lattimer SA, Sima AAF (1988) Perspectives in diabetes: are disturbances of sorbitol phosphoinositide, and $\mathrm{Na}^{+}-\mathrm{K}^{+}-$ATPase regulation involved in pathogenesis of diabetic neuropathy? Diabetes 37: 688-693

6. Cohen MP (1989) Nonenzymatic glycation and enhanced polyol pathway activity in the pathogenesis of diabetic neuropathy. Contrib Nephrol 73: 59-72

7. Cerami A, Stevens VJ, Monnier VM (1979) Role of nonenzymatic glycosylation in the development of the sequelae of diabetes mellitus. Metabolism 28[Suppl. 1]: 431-437

8. Brownlee M, Cerami A (1981) The biochemistry of the complications of diabetes mellitus. Ann Rev Biochem 50: $385-432$

9. Kennedy L, Baynes JW (1981) Nonenzymatic glycosylation and the chronic complications of diabetes: an overview. Diabetologia 26: 93-98

10. Akagi Y, Yajima Y, Kador PF, Kuwabara T, Kinoshita JH (1984) Localization of aldose reductase in the human eye. Diabetes 33: 562-566

11. Ludvigson MA, Sorenson RL (1980) Immunohistochemical localization of aldose reductase. II. Rat eye and kidney. Diabetes 29: 450-459

12. Akagi Y, Kador PF, Kuwabara T, Kinoshita JH (1983) Aldose reductase localization in human retinal mural cells. Invest Ophthalmol Vis Sci 24: $1516-1519$ 
13. Ludvigson MA, Sorenson RL (1980) Immunohistochemical localization of aldose reductase. I. Enzyme purification and antibody preparation: localization in peripheral nerve, artery, and testis. Diabetes 29: 438-449

14. Nishimura C, Matsuura Y, Kokai Y et al. (1990) Cloning and expression of human aldose reductase. $\mathrm{J}$ Biol Chem 265: 9788-9792

15. Nishi M, Ishida Y, Honjo T (1988) Expression of functional interleukin-2 receptors in human light chain/Tac transgenic mice. Nature 331: 267-269

16. Ishida Y, Nishi M, Taguchi O et al. (1989) Effects of the deregulated expression of human interleukin-2 in transgenic mice. Int Immunol 1: 113-120

17. Sambrook J, Fritsch EF, Maniatis T (1989) Molecular cloning: a laboratory manual. 2nd edn. Cold Spring Harbor Laboratory, New York

18. Hogan B, Costantini F, Lacy E (1986) Manipulating the mouse embryo: a laboratory manual. Cold Spring Harbor Laboratory, New York

19. Harlow E, Lane D (1988) Antibodies: a laboratory manual. Cold Spring Harbor Laboratory, New York

20. Morjano NA, Flynn TG (1989) Aldose reductase from human psoas muscle: purification, substrate specificity, immunological characterization, and effect of drugs and inhibitors. J Biol Chem 264: 2906-2911

21. Yamaoka T, Matsuura $Y$, Yamashita $K$, Tanimoto $T$, Nishimura C (1992) Site-directed mutagenesis of His-42, His-188, and Lys-263 of human aldose reductase. Biochem Biophys Res Commun 183: 327-333
22. Nishimura C, Furue M, Ito T, Omori Y, Tanimoto T (1993) Quantitative determination of human aldose reductase by enzyme-linked immunosorbent assay. Biochem Pharmacol 46: 21-28

23. Bohren KM, Bullock B, Wermuth B, Gabbay KH (1989) The aldo-keto reductase superfamily: cDNAs and deduced amino acid sequences of human aldehyde and aldose reductases. J Biol Chem 264: 9547-9551

24. Pailhoux EA, Martinez A, Veyssiere GM, Jean CG (1990) Androgen-dependent protein from mouse vas deferens: cDNA cloning and protein homology with the aldo-keto reductase superfamily. J Biol Chem 265: 19932-19936

25. Ludvigson MA, Waites GMH, Hamilton DW (1982) Immunocytochemical evidence for the specific localization of aldose reductase in rat Sertoli cells. Biol Reprod 26: 311317

26. van Heyningen R (1959) Formation of polyols by the lens of the rat with sugar cataract. Nature 184: 194-195

27. Robins SL, Cotran RS, Kumar V (1984) The kidney. In: Pathologic basis of disease. W. B. Saunders Co, Philadelphia, pp 1022-1025

28. Engerman, RL, Kern TS (1984) Experimental galactosemia produces diabetic-like retinopathy. Diabetes 33: 97100

29. Dvornik D (1987) Aldose reductase inhibitors. In: Porte D (ed) Aldose reductase inhibition: an approach to the prevention of diabetic complications. Biomedical Information Corporation, New York, pp 221-323 